\title{
Kearifan Lokal Masyarakat Pesisir dalam Memahami Teknologi Hasil Perikanan
}

\section{Dati Nawastuti}

Teknologi Hasil Pertanian, Institut Keguruan dan Teknologi Larantuka, Indonesia Korespondensi penulis: nawastuti.dati78@gmail.com

\begin{abstract}
Characteristics of people in coastal area are taught and open mind like sea which is analog to open access and high risk. They inherit knowledge from their ancestors who refered to stars constelation as guide, besides other traditional technologies. There are four research questions: (1) How are technologies inherited to young generations? (2) Are the developing fish technologies accepted? (3) What are governments', scholars', and NGO's roles? and (4) How is people's responds towards modern technologies? Meanwhile, this research wants: (1) To know inheritance technologies, (2) To understand acceptability level, (3) To explore the roles' of governments, NGOs, and scholars, and (4) To recognize people's respond toward technologies. Fisheries commodities have comparative advance, although they are perishable food that need quick, accurate, and right treatment. The research was conducted in Larantuka Sub-district of East Flores. Observation and interview were data collection methods applied in this research. Data were analysed using SWOT analysis. It is concluded that traditional technologies are useful to preserve local culture and wisdom. The role of government through local development agents, NGOs, and scholars via trainning has not applicable yet for the community in the wide area and has limitations of man power.
\end{abstract}

Keywords: Local wisdom, People in seashore, Post-harvest fisheries technology.

Abstrak: Karakteristik masyarakat pesisir yang tegas, keras dan terbuka sama seperti laut yang bersifat open access dan beresiko tinggi. Mereka mewarisi pengetahuan nenek moyang dengan menggunakan rasi bintang sebagai penunjuk arah, selain teknologi tradisional yang masih dilakukan. Berdasarkan latar belakang dirumuskan: (1) bagaimana pewarisan teknologi tradisional pada generasi muda?; (2) apakah teknologi hasil perikanan yang berkembang dapat diterima?; (3) apakah peran pemerintah, lembaga nonpemerintah dan akademisi? dan (4) bagaimana tanggapan masyarakat pesisir terhadap teknologi modern? Tujuan penelitian ini: (1) mengetahui warisan teknologi tradisional, (2) mengetahui tingkat akseptabilitas masyarakat (3) mengetahui peranan pemerintah, lembaga non-pemerintah dan akademisi dan (4) memahami tanggapan masyarakat terhadap teknologi. Komoditas perikanan memiliki keunggulan komparatif walaupun memiliki sifat perishable food sehingga diperlukan penanganan cepat, tepat dan benar. Penelitian dilaksanakan di Kecamatan Titehena Kabupaten Flores Timur. Metode observasi dan wawancara, serta analisis SWOT. Berdasarkan kajian ini, teknologi tradisional bermanfaat melestarikan budaya dan kearifan lokal namun tidak menutup teknologi modern. Peran pemerintah melalui pendamping desa, lembaga non-pemerintah 
dan akademisi lewat pelatihan belum menyentuh masyarakat karena luasnya area dan keterbatasan tenaga.

Article Info:

Received: August 12, $2018 \quad$ Accepted: October 10, 2018

DOI: http://dx.doi.org/10.30588/jmp.v8i1.374

Available Online: December 12, 2018

\section{PENDAHULUAN}

Kearifan lokal merupakan bagian dari budaya suatu masyarakat yang tidak dapat dipisahkan dari bahasa masyarakat itu sendiri. Kearifan lokal biasanya diwariskan secara turun temurun dari satu generasi ke generasi berikutnya melalui cerita dari mulut ke mulut. Kearifan lokal sebagai suatu pengetahuan yang ditemukan oleh masyarakat lokal tertentu melalui kumpulan pengalaman dalam mencoba dan mengintegrasikannya dengan pemahaman mereka terhadap budaya dan keadaan alam suatu tempat (https://id.m. wikipedia.org).

Teknologi yang menggunakan kearifan lokal dalam bidang perikanan dapat dilihat pada saat masyarakat nelayan akan melaut, tidak jarang mereka akan melihat kondisi bulan di langit. Apabila saat bulan gelap hingga nampak separuh, maka nelayan dapat melaut dan membawa hasil yang cukup berlimpah. Namun, apabila kondisi bulan separuh hingga penuh (bulan purnama), maka nelayan tidak akan memperoleh hasil yang melimpah. Pada saat seperti itu, nelayan akan lebih banyak menggunakan waktunya untuk memperbaiki jala dan mengecat perahu (Nawastuti et al., 2018).

Masih banyak nelayan tradisional yang belum menggunakan alat GPS (Global Positioning System) untuk mendapatkan hasil tangkapan, karena keterbatasan daya beli dan masih menganggap bahwa laut masih bisa memberi mereka hasil tangkapan yang banyak. Saat ini, nelayan merasa agak kesulitan menangkap ikan karena banyaknya armada kapal, baik milik pribadi, kelompok, maupun perusahaan. Padahal, rumponrumpon sangat jarang ditemukan. Masyarakat pesisir di Kabupaten Flores Timur, Nusa Tenggara Timur belum membudidayakan ikan dalam rumpon. Rumpon merupakan tempat bertelur bagi ikan-ikan, sehingga sangat vital bagi keberlanjutan produksi tangkapan ikan yang masih tradisional.

Tujuan yang ingin dicapai dalam penelitian ini adalah: (1) mengetahui warisan teknologi tradisional, (2) mengetahui tingkat akseptabilitas masyarakat, (3) mengetahui peranan pemerintah, lembaga non-pemerintah, dan akademisi, dan (4) memahami tanggapan masyarakat terhadap teknologi.

\section{TINJAUAN TEORITIS}

\section{A. Masyarakat Pesisir}

Pesisir merupakan daerah pertemuan antara darat dan laut. Apabila ke arah darat, maka meliputi bagian daratan, baik kering maupun terendam air yang masih dipengaruhi sifat-sifat laut seperti pasang surut, angin laut, dan perembesan air asin, sedangkan ke arah laut meliputi bagian laut yang masih dipengaruhi oleh proses-proses alami yang terjadi di darat, seperti sedimentasi dan aliran air tawar maupun yang disebabkan oleh 
kegiatan manusia di darat seperti penggundulan hutan dan pencemaran (http://id.wikipediaorg/ wiki/Pesisir).

Berdasarkan Keputusan Menteri Kelautan dan Perikanan Nomor KEP.10/MEN/ 2002 tentang Pedoman Umum Perencanaan Pengelolaan Pesisir Terpadu, wilayah pesisir didefinisikan sebagai wilayah peralihan antara ekosistem darat dan laut yang saling berinteraksi, yaitu ke arah laut 12 mil dari garis pantai untuk provinsi dan sepertiga dari wilayah laut itu (kewenangan provinsi) untuk kabupaten/kota dan ke arah darat batas administrasi kabupaten/kota.

Secara teoritis, masyarakat pesisir merupakan masyarakat yang tinggal dan melakukan aktivitas sosial ekonomi yang terkait dengan sumber daya wilayah pesisir dan lautan. Dengan demikian, dalam pengertian secara sempit masyarakat pesisir memiliki ketergantungan yang cukup tinggi dengan potensi dan kondisi sumber daya pesisir dan lautan. Namun, secara luas masyarakat pesisir dapat pula didefinisikan sebagai masyarakat yang tinggal secara spasial di wilayah pesisir tanpa mempertimbangkan apakah mereka memiliki aktivitas sosial ekonomi yang terkait dengan potensi dan kondisi sumber daya pesisir dan lautan (Sulviyana et al., 2012).

Menurut Satria (2002), masyarakat pesisir didefinisikan sebagai kelompok orang atau suatu komunitas yang tinggal di daerah pesisir dan sumber kehidupan perekonomiannya bergantung secara langsung pada pemanfaatan sumber daya laut dan pesisir. Desa pesisir merupakan entitas sosial, ekonomi, ekologi, dan budaya yang menjadi batas antara daratan dan lautan. Wilayah tersebut terdapat sekelompok manusia yang memiliki pola hidup dan tingkah laku, serta karakteristik tertentu. Mereka menjadi pelaku utama dalam pembangunan kelautan dan perikanan, serta pembentuk suatu budaya dalam kehidupan masyarakat pesisir. Banyak di antara faktor-faktor yang menyebabkan masyarakat pesisir menjadi suatu komunitas yang terbelakang atau bahkan terisolasi, sehingga upaya untuk menjadikan masyarakatnya sejahtera masih jauh. Faktor internal masyarakat pesisir secara umum kurang terbuka terhadap teknologi dan pengelolaan sumber daya kelautan dengan kultur masyarakat setempat.

\section{B. Definisi dan Kondisi Umum Kemiskinan}

Kemiskinan diartikan sebagai suatu keadaan ketika seseorang tidak sanggup memelihara dirinya sendiri sesuai dengan taraf kehidupan kelompok dan juga tidak mampu memanfaatkan tenaga, mental, maupun fisiknya dalam kelompok tersebut (Soekanto, 2006). Menurut Kementerian Sosial, kemiskinan merupakan sebuah kondisi yang berada di bawah garis nilai standar kebutuhan minimum, baik untuk makanan dan non-makanan, yang disebut sebagai garis kemiskinan (poverty line) atau batas kemiskinan (poverty threshold). Garis kemiskinan adalah sejumlah nilai rupiah yang diperlukan oleh setiap individu untuk dapat membayar kebutuhan makanan yang setara 2.100 kilo kalori per orang per hari dan kebutuhan non-makanan yang terdiri atas perumahan, pakaian, kesehatan, pendidikan, dan transportasi, serta aneka barang dan jasa lainnya (Suharto, 2005). 


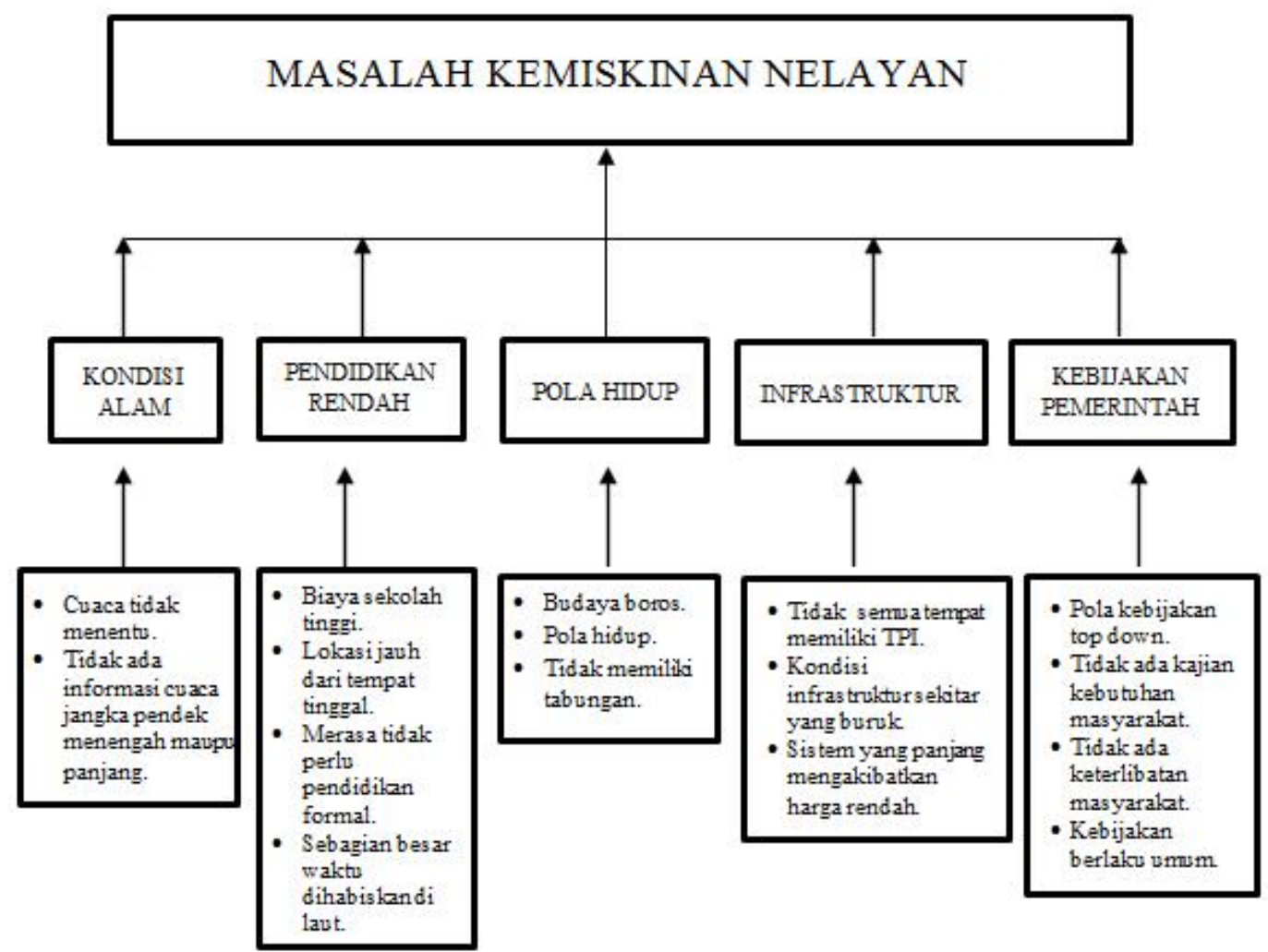

Sumber: https://www.rahmatullah.net

\section{Gambar 1. Struktur Masalah Kemiskinan Nelayan}

Salah satu usaha untuk mengentaskan kemiskinan nelayan adalah dengan memberikan pinjaman modal usaha melalui Lembaga Keuangan Mikro (LKM). Hal itu meliputi pemberian pelayanan berupa jasa pinjaman, pembiayaan usaha mikro, dan pengelolaan simpanan yang harus tetap memperhatikan kemampuan peminjam untuk mengangsur pokok dan bunga pinjaman tersebut (Nawastuti, 2017).

Pinjaman tersebut diharapkan dapat membantu perekonomian masyarakat pesisir dengan kearifan lokal yang masih berlaku saat ini. Pinjaman tersebut dapat berupa modal untuk berdagang, membeli peralatan teknologi tepat guna yang sederhana untuk mengolah ikan hasil tangkapan, hingga bagan (kapal ikan) untuk kebutuhan melaut. Teknologi pengolahan ikan yang ada saat ini masih banyak menggunakan cara tradisional, sehingga baik dari segi kualitas maupun kuantitasnya belum terjamin. Pemenuhan kebutuhan pasar yang lebih luas membutuhkan teknologi pengolahan ikan yang lebih modern dan keberlanjutan usaha agar tidak ada lagi keluhan mengenai keterbelakangan dan kemiskinan masyarakat pesisir.

\section{Kabupaten Flores Timur}

Kabupaten Flores Timur di Nusa Tenggara Timur (NTT) memiliki 19 Kecamatan dan 229 Desa, serta 21 Kelurahan. Kecamatan-kecamatan tersebut meliputi Kecamatan Wulanggitang, Ile Bura, Titehena, Demon Pagong, Larantuka, Ile Mandiri, Lewolema, Tanjung Bunga, Solor Barat, Solor Timur, Solor Selatan, Wotan Ulumado, Adonara, 
Adonara Tengah, Adonara Barat, Adonara Timur, Ile Boleng, Witihama, dan Kelubagolit. Jumlah penduduk Flores Timur mencapai 226.894 jiwa pada tahun 2006 dengan beragam jenis pekerjaan. Menurut data BPS (2006), jenis pekerjaan yang dilakukan oleh penduduk berumur 15 tahun ke atas menurut lapangan usahanya, antara lain pertanian dan perikanan (63.467 jiwa); industri pengolahan (5.806 jiwa); listrik, gas, dan air (262 jiwa); konstruksi (839 jiwa); perdagangan, angkutan, pergudangan, dan telekomunikasi (9.158 jiwa); keuangan, asuransi, usaha persewaan, dan bangunan (339 jiwa), dan jasa kemasyarakatan (9.956 jiwa).

Di daratan Flores terdapat Selat Gonsalu yang melalui beberapa Desa/Kelurahan Pesisir, antara lain Postoh, Amagarapati, Ekasapta, Pohon Bao, Waihali, Pukentobi Wangi Bao, Sarotari, Sarotari Tengah, Sarotari Timur, Weri, Tiwatobi, Watotutu, Halokodanuan, Kainapang, dan Kolaka. Selat Gonsalu yang melintasi Pulau Adonara antara lain Wailebe, Beliko, Ariona, Wure, Bogalima, dan Pajinian. Selain itu, ada pula Selat Solor yang melintasi Desa/Kelurahan di daratan Flores antara lain Lewolere, Waibalun, Lamawalang, Wailolong, Mokantarak, Bama, Kawalelo, Lewomuda, Lewoingu, Duntana, Lewolaga, Konga, Nobo, Nurebelen, dan Riarita. Di Pulau Solor, desa-desa pesisir yang dilintasi Selat Solor, antara lain Ritaebang, Nusadani, Daniwato, Balaweling II, Balaweling I, Karawutung, dan Pamakayo. Banyaknya desa-desa pesisir tersebut merupakan aset yang sangat potensial untuk mengembangkan wilayah pesisir agar masyarakatnya menjadi lebih maju. Namun, hal itu memerlukan strategi yang tepat untuk memulainya dari peningkatan sumber daya manusia (SDM) hingga teknologi pengolahan hasil perikanan.

\section{Teknologi Hasil Perikanan}

\section{Teknologi Hasil Perikanan secara Tradisional}

Cara tradisional yang umum dilakukan oleh para nelayan dalam teknologi hasil perikanan untuk pengawetan ikan, antara lain dengan melakukan pengeringan, pengasapan, dan fermentasi. Pengeringan bertujuan untuk mengurangi kadar air di dalam daging ikan, sehingga kegiatan mikro-organisme pembusuk dan enzim penyebab pembusukan dapat berhenti. Pengeringan ikan umumnya disertai dengan penggaraman, sehingga saat kering ikan tersebut terasa asin.

Tujuan dari penggaraman ikan adalah untuk menyerap air dari permukaan ikan dan mengawetkannya, sehingga aktivitas bakteri akan terhambat. Selain itu, larutan garam juga menyebabkan proses osmosis pada sel-sel mikro-organisme, sehingga terjadi plasmosis yang mengakibatkan kurangnya kadar air pada sel bakteri dan akhirnya sel tersebut menjadi kering dan kemudian mati. Batas kadar air yang diperlukan dalam tubuh ikan kira-kira 20\%-35\%, sehingga perkembangan mikro-organisme pembusuk bisa terhenti. Pengasapan bertujuan untuk mengawetkan ikan dengan menggunakan panas dari asap yang tinggi dan dapat menghentikan aktivitas mikroba pembusuk dan enzim perusak dalam daging.

Fermentasi merupakan proses penguraian senyawa-senyawa kompleks yang terdapat di dalam tubuh ikan menjadi senyawa-senyawa yang lebih sederhana. Proses ini membutuhkan bantuan enzim yang berasal dari tubuh ikan atau dari mikro-organisme. Proses fermentasi ini berlangsung dalam kondisi lingkungan yang terkontrol. Produkproduk fermentasi ikan, antara lain ikan peda, terasi, kecap ikan, bekasem, dan silase ikan. 


\section{Teknologi Hasil Perikanan secara Modern}

Kemajuan ilmu pengetahuan dan teknologi mempengaruhi cara pengawetan ikan. Cara modern ini biasanya menggunakan alat-alat canggih dan membutuhkan biaya yang besar. Mutu pengawetan ikan yang dihasilkan bisa dipertanggungjawabkan. Oleh karena itu, cara ini biasanya digunakan oleh perusahaan makanan yang mengolah ikan secara besar-besaran untuk dipasarkan. Pengawetan dengan cara modern melalui pengawetan dengan menggunakan suhu rendah (pendinginan dan pembekuan), canning, serta fishmeal.

Di antara cara-cara mempertahankan kesegaran atau mengawetkan ikan yang paling sempurna dan bisa mempertahankan sifat-sifat mendekati sifat ikan segar, yaitu dengan menggunakan suhu rendah. Pada suhu di atas $0^{\circ} \mathrm{C}$, ikan akan membusuk dengan cepat, sehingga perlu diawetkan dalam hancuran es atau mendinginkannya untuk beberapa waktu. Pengawetan dengan suhu rendah meliputi pendinginan dan pembekuan. Kedua cara tersebut mempunyai prinsip yang sama, yaitu mengurangi atau menghentikan aktivitas organisme pembusuk.

Salah satu industri pengolahan ikan yang cukup berkembang di Indonesia, yaitu industri pengalengan ikan. Saat ini, industri tersebut berjumlah 41 perusahaan dengan jumlah pekerja mencapai 46.500 orang dan nilai investasi mencapai Rp1,91 triliun. Kapasitas terpasang industri ini mencapai 630.000 ton dengan nilai produksi 315.000 ton pada tahun 2015 (utilisasi produksi hanya 50\%). Selanjutnya pada tahun 2015, nilai ekspor ikan dalam kaleng mencapai USD 23 juta dengan nilai impornya sebesar USD 1,9 juta (https://www.kemenperin.go.id).

\section{Karakteristik Masyarakat Pesisir}

Karakteristik masyarakat pesisir berbeda dengan karakterisik masyarakat agraris atau petani. Dari segi penghasilan, petani mempunyai pendapatan yang dapat dikontrol karena pola panen yang terkontrol, sehingga hasil pangan atau ternak yang mereka miliki dapat ditentukan untuk mencapai hasil pendapatan yang mereka inginkan. Berbeda halnya dengan masyarakat pesisir yang mata pencahariannya di laut sebagai nelayan. Nelayan menghadapi sumber daya yang bersifat open access dan berisiko tinggi. Hal tersebut menyebabkan masyarakat pesisir, seperti nelayan memiliki karakter yang tegas, keras, dan terbuka (Satria, 2002).

Selain itu, karakteristik masyarakat pesisir dapat dilihat dari beberapa aspek di antaranya: aspek pengetahuan, kepercayaan (teologis), dan posisi nelayan sosial. Dilihat dari aspek pengetahuan, masyarakat pesisir mendapat pengetahuan dari warisan nenek moyangnya, misalnya untuk melihat kalender dan penunjuk arah, maka mereka menggunakan rasi bintang. Sementara, dilihat dari aspek kepercayaan, masyarakat pesisir masih menganggap bahwa laut memiliki kekuatan magic, sehingga mereka masih sering melakukan adat pesta laut atau sedekah laut.

Adat istiadat suku yang bermukim di wilayah pesisir dan pulau-pulau kecil sangatlah beragam. Di beberapa tempat sering dijumpai adanya budaya pengaturan lahan laut atau sering disebut Hak Ulayat Laut. Aturan-aturan semacam ini merupakan sebuah kearifan lokal yang perlu dihargai sesuai dengan UUD 1945 Pasal 18B ayat 2, yaitu negara mengakui dan menghormati kesatuan-kesatuan masyarakat hukum adat beserta hak-hak tradisionalnya sepanjang hidup dan sesuai dengan perkembangan masyarakat dan prinsip Negara Kesatuan Republik Indonesia yang diatur dengan Undang-Undang. 
Kebudayaan masyarakat pesisir dapat diartikan sebagai keseluruhan pengetahuan atau sistem kognisi yang ada dan berkembang pada masyarakat pesisir yang berisi perangkat-perangkat model pengetahuan yang secara selektif dapat digunakan untuk memahami dan menginterpretasi lingkungan yang dihadapi untuk mendorong dan menciptakan kelakuan-kelakuan yang diperlukan.

Dari uraian di atas, permasalahan yang dirumuskan dalam penelitian ini adalah (1) Bagaimana pewarisan teknologi tradisional pada generasi muda? (2) Apakah teknologi hasil perikanan yang berkembang dapat diterima? (3) Apakah peran pemerintah, lembaga non-pemerintah, dan akademisi? dan (4) Bagaimana tanggapan masyarakat pesisir terhadap teknologi modern?

\section{METODE PENELITIAN}

Penelitian dilaksanakan di Kelurahan Lewolere, Kecamatan Larantuka, Kabupaten Flores Timur, Nusa Tenggara Timur. Penentuan daerah penelitian dilakukan secara sengaja (purposive) dengan pertimbangan bahwa wilayah tersebut berada di pesisir laut. Data penelitian diperoleh dari data primer yang diperoleh langsung dari lapangan melalui daftar pertanyaan dengan teknik pengambilan sampel secara sengaja (purposive sampling) dan data sekunder yang berasal dari Badan Pusat Statistik dan instansi lain yang terkait. Peneliti bertindak sebagai pengumpul data utama dari 20 responden yang bekerja sebagai nelayan. Penelitian ini menggunakan data yang diambil dari kegiatan nelayan selama satu bulan, yaitu dari tanggal 1 sampai dengan 28 Februari 2017.

Pengumpulan data menggunakan metode observasi, yaitu melakukan pengamatan langsung keadaan obyek di lapangan dan metode wawancara, yaitu melakukan tanya jawab kepada pelaku usaha dengan panduan pertanyaan yang telah dibuat dan disusun sebelumnya untuk mendapatkan informasi yang berkaitan dengan kegiatan penelitian.

Metode analisis yang digunakan adalah analisis SWOT. SWOT merupakan suatu metode perencanaan strategis yang digunakan untuk mengevaluasi kekuatan (strengths), kelemahan (weaknesses), peluang (opportunities), dan ancaman (threats). SWOT akan lebih baik dibahas dengan menggunakan tabel yang dibuat dalam kertas besar, sehingga dapat dilakukan analisis terhadap hubungan dari setiap aspek. Proses ini melibatkan penentuan tujuan yang spesifik dari spekulasi bisnis atau proyek dan mengidentifikasi faktor internal dan eksternal yang mendukung dan yang tidak mendukung dalam mencapai tujuan tersebut. Analisis SWOT dapat diterapkan dengan cara menganalisis dan memilah berbagai hal yang mempengaruhi keempat faktornya. Selanjutnya, peneliti menerapkannya dalam gambar matriks SWOT yang aplikasinya adalah bagaimana kekuatan (strengths) mampu mengambil keuntungan (advantage) dari peluang (opportunities) yang ada, bagaimana cara mengatasi kelemahan (weaknesses) yang mencegah keuntungan (advantage) dari peluang (opportunities) yang ada. Selanjutnya, bagaimana kekuatan (strengths) mampu menghadapi ancaman (threats) yang ada, dan terakhir adalah bagaimana cara mengatasi kelemahan (weaknesses) yang mampu membuat ancaman (threats) menjadi nyata atau menciptakan sebuah ancaman baru (https://id.wikipedia.org/wiki/Analisis_SWOT). 


\section{HASIL DAN PEMBAHASAN}

\section{A. Hasil}

Tabel 1 menggambarkan keseluruhan analisis yang merupakan gabungan dari beberapa program pemerintah, dukungan pihak lain, produktivitas, dan kendala yang dihadapi oleh masyarakat pesisir. Berdasarkan kondisi masyarakat setempat, maka dibutuhkan dukungan dari pemerintah dan pihak lain, yaitu bagaimana memanfaatkan teknologi, akses informasi mengenai titik-titik keberadaan ikan dengan menggunakan GPS, serta dukungan dari pengusaha atau pihak akademik mengenai teknologi pengawetan dan pengemasan, agar harga ikan tidak mengalami kejatuhan.

\section{Tabel 1. Ilustrasi SWOT Personal sebagai Alat Perumus Strategi Masyarakat Pesisir Memahami Teknologi Hasil Perikanan}

\section{Strengths (Kekuatan)}

1. Program yang dilakukan oleh pemerintah untuk menanggulangi kemiskinan nelayan yaitu Program Pemerintah, antara lain Program Gerbang Emas, Program Anggur Merah, Program Pengembangan Usaha Agribisnis Perdesaan (PUAP), Program Nasional Pembangunan Masyarakat (PNPM), dan Kredit Usaha Rakyat (KUR).

2. Masyarakat pada umumnya sangat menerima kemajuan teknologi terutama di bidang perikanan.

\section{Weaknesses (Kelemahan)}

1. Nelayan pada umumnya belum banyak tersentuh teknologi modern.

2. Kualitas sumber daya manusianya rendah.

3. Tingkat produktivitas hasil tangkapannya rendah.

4. Rendahnya tingkat penguasaan nelayan terhadap teknologi modern.
Opportunities (Peluang)

1. Teknologi pengawetan ikan yang tepat.

2. Dukungan pemerintah dan pihak lain yang sangat dibutuhkan adalah pemanfaatan teknologi untuk mengakses informasi mengenai titik-titik keberadaan ikan.

3. Dukungan dari pengusaha atau pihak akademik mengenai teknologi pengawetan dan pengemasan harus diberikan agar harga ikan yang nelayan jual tidak mengalami kejatuhan.

\section{Threats (Ancaman)}

1. Kurangnya kesempatan berusaha, kurangnya akses terhadap informasi, teknologi dan permodalan, budaya dan gaya hidup yang cenderung boros, menyebabkan posisi tawar masyarakat miskin semakin lemah.

2. Kebijakan Pemerintah selama ini kurang berpihak pada masyarakat pesisir sebagai salah satu pemangku kepentingan di wilayah pesisir.

3. Formulasi kebijakan yang bersifat top down.

4. Formula yang diberikan cenderung seragam padahal masalah yang dihadapi nelayan sangat beragam dan seringkali sangat spesifik/lokal.

5. Kendala yang sering terjadi adalah kurangnya informasi yang didapat oleh masyarakat.

6. Terjadi tebang pilih dalam proses pelatihan dan pembagian bantuan baik berupa modal kerja hingga kapal penangkap ikan.

7. Ikan cepat sekali mengalami proses pembusukan dibandingkan dengan bahan makanan lain. 
Tabel 2 menggambarkan faktor internal dan faktor eksternal yang dihadapi oleh masyarakat pesisir di Kecamatan Larantuka. Pada faktor internal terdapat tiga hal, yaitu sumber daya yang dimiliki, keuangan, dan pengetahuan teknologi. Sumber daya yang dimiliki oleh masyarakat, yaitu memiliki garis pantai yang cukup panjang karena Kabupaten Flores Timur adalah kabupaten kepulauan. Banyaknya koperasi/Lembaga Keuangan Mikro (LKM) di daerah setempat, memudahkan para nelayan untuk mendapatkan pinjaman modal untuk kebutuhan melaut. Walaupun pengetahuan teknologi masyarakatnya masih tradisional, tetapi tidak menghambat para nelayan untuk melaut dan mendapatkan hasil tangkapan.

Faktor eksternal meliputi trend, budaya, sosial, perubahan teknologi, dan risiko yang ada dalam usaha pengolahan ikan. Perubahan teknologi yang lebih maju diharapkan dapat membuat para nelayan lebih meningkatkan hasil tangkapannya.

\section{Tabel 2. Faktor Internal dan Faktor Eksternal}

\begin{tabular}{ll}
\hline FAKTOR INTERNAL (STRENGTHS AND & FAKTOR EKSTERNAL (OPPORTUNITIES \\
WEAKNESSES) & AND THREATS) \\
1. Sumber daya yang dimiliki. & 1. Trend. \\
2. Keuangan atau finansial. & 2. Budaya dan sosial. \\
3. Pengetahuan teknologi. & 3. Perubahan teknologi. \\
& 4. Risiko yang ada dalam usaha pengolahan ikan. \\
\hline
\end{tabular}

Tabel 3 menggambarkan strategi SWOT yang terdiri atas strategi SO, WO, ST, dan WT. Strategi SO dibuat untuk memanfaatkan seluruh kekuatan dalam merebut dan memanfaatkan peluang sebesar-besarnya. Strategi WO diterapkan berdasarkan pemanfaatan peluang yang ada dengan cara meminimalkan kelemahan yang ada. Strategi ST menggunakan kekuatan yang dimiliki perusahaan untuk mengatasi ancaman. Strategi WT didasarkan pada kegiatan defensif dan berusaha meminimalkan kelemahan yang ada dan menghindari ancaman.

Tabel 3. Tabel Strategi SWOT

\begin{tabular}{cll}
\hline \multicolumn{1}{c}{ Eksternal } & \multicolumn{1}{c}{ Opportunities $(\mathbf{O})$} & \multicolumn{1}{c}{ Threats $(\mathbf{T})$} \\
\hline \multicolumn{1}{l|}{ Internal } & Strategi SO & Strategi ST \\
\hline Strengths $(\mathrm{S})$ & Strategi WO & Strategi WT \\
\hline Weaknesses $(\mathrm{W})$ &
\end{tabular}

\section{B. PEMBAHASAN}

Berdasarkan hasil penelitian, maka dapat dijelaskan berikut ini pada masing-masing strategi yang dimaksud pada Tabel 3.

\section{Strategi SO}

Beberapa program dilaksanakan oleh pemerintah untuk menanggulangi kemiskinan nelayan. Dukungan pemerintah dan pihak lain dalam teknologi pengawetan ikan, masalah pemanfaatan teknologi, akses informasi mengenai 
titik-titik keberadaan ikan, dan cara pengemasan yang tepat diperlukan agar harga jual ikan tidak jatuh.

\section{Strategi ST}

Masyarakat pada umumnya sangat menerima kemajuan teknologi terutama di bidang perikanan, tetapi: (1) Kurangnya kesempatan berusaha; kurangnya akses terhadap informasi, teknologi, dan permodalan; serta budaya dan gaya hidup yang cenderung boros dapat menyebabkan posisi tawar masyarakat miskin semakin lemah; (2) Kebijakan pemerintah selama ini kurang berpihak pada masyarakat pesisir sebagai salah satu pemangku kepentingan di wilayah pesisir; (3) Formulasi kebijakan cenderung bersifat top down; (4) Formula yang diberikan juga cenderung seragam, padahal masalah yang dihadapi nelayan sangat beragam dan seringkali sangat spesifik/lokal; (5) Kendala yang sering terjadi adalah kurangnya informasi yang didapat oleh masyarakat; (6) Terjadi tebang pilih dalam proses pelatihan dan pembagian bantuan baik berupa modal kerja hingga kapal penangkap ikan; dan (7) Ikan cepat sekali mengalami proses pembusukan dibandingkan dengan bahan makanan lain.

\section{Strategi WO}

Pada umumnya, nelayan belum banyak tersentuh teknologi modern dan juga kualitas sumber daya manusianya yang relatif masih rendah, sehingga tingkat produktivitas hasil tangkapannya juga rendah. Hal ini disebabkan karena rendahnya tingkat penguasaan nelayan terhadap teknologi modern. Namun, hal ini dapat diatasi dengan teknologi pengawetan ikan yang tepat dan dukungan pemerintah maupun pihak lain dalam memanfaatkan teknologi, akses informasi mengenai titik-titik keberadaan ikan, dan cara pengemasan hasil perikanan yang harus diberikan, agar harga ikan yang mereka jual tidak jatuh harganya.

\section{Strategi WT}

Nelayan pada umumnya belum banyak tersentuh teknologi modern dan juga kualitas sumber daya manusianya yang rendah, sehingga tingkat produktivitas hasil tangkapannya juga rendah hal ini disebabkan karena rendahnya tingkat penguasaan nelayan terhadap teknologi modern. Keadaan akan semakin memburuk apabila: (1) Nelayan kurang mendapatkan kesempatan berusaha, kurang memiliki akses terhadap informasi, teknologi, dan permodalan, memiliki budaya dan gaya hidup yang cenderung boros, dan menyebabkan posisi tawar masyarakat miskin semakin lemah; (2) Kebijakan pemerintah selama ini kurang berpihak pada masyarakat pesisir sebagai salah satu pemangku kepentingan di wilayah pesisir; (3) Formulasi kebijakan yang bersifat top down; (4) Formula yang diberikan cenderung seragam, padahal masalah yang dihadapi nelayan sangat beragam dan seringkali sangat spesifik/lokal; (5) Kendala yang sering terjadi adalah kurangnya informasi yang didapat oleh masyarakat; (6) Terjadi tebang pilih dalam proses pelatihan dan pembagian bantuan baik berupa modal kerja hingga kapal penangkap ikan; dan (7) Ikan cepat sekali mengalami proses pembusukan dibandingkan dengan bahan makanan lain.

Berdasarkan rumusan masalah sebelumnya, yaitu: (1) Bagaimana pewarisan teknologi tradisional pada generasi muda? (2) Apakah teknologi hasil perikanan yang berkembang dapat diterima? (3) Apakah peran pemerintah, lembaga non-pemerintah dan 
akademisi? dan (4) Bagaimana tanggapan masyarakat pesisir terhadap teknologi modern? Berikut ini adalah jawaban dari hasil penelitian yang telah dilaksanakan dengan menggunakan analisis SWOT.

\section{Pewarisan Teknologi Tradisional pada Generasi Muda}

Nelayan pada umumnya belum banyak tersentuh teknologi modern sehingga kualitas sumber daya manusia dan tingkat produktivitas hasil tangkapannya rendah. Tingkat pendidikan nelayan berbanding lurus dengan teknologi yang dihasilkan dalam hal ini teknologi di bidang penangkapan dan pengawetan ikan. Ikan cepat sekali mengalami proses pembusukan dibandingkan dengan bahan makanan lain yang disebabkan oleh bakteri dan perubahan kimiawi. Oleh karena itu, perlu dukungan teknologi pengawetan ikan yang tepat. Selama ini, nelayan hanya menggunakan cara tradisional untuk mengawetkan ikan. Hal tersebut salah satunya disebabkan karena rendahnya tingkat penguasaaan nelayan terhadap teknologi.

Teknologi penangkapan secara tradisional yang dilakukan oleh masyarakat nelayan, misalnya untuk mengetahui lokasi penangkapan ikan masih memakai cara petunjuk arah bintang. Melihat jumlah ikan banyak atau sedikit, nelayan menggunakan persepsi cahaya bulan. Bila cahaya bulan terang, maka diasumsikan jumlah ikan hanya sedikit karena ikan lebih banyak menyebar, sehingga nelayan agak kesulitan menangkap ikan dalam jumlah yang berlimpah.

\section{Teknologi Hasil Perikanan Modern}

Dukungan pemerintah dan pihak lain sangat dibutuhkan oleh nelayan, karena kelemahan utama nelayan di Indonesia dibandingkan nelayan bangsa lain adalah masalah pemanfaatan teknologi, akses informasi mengenai titik-titik keberadaan ikan yang tidak mereka miliki, sehingga jumlah tangkapan nelayan selalu terbatas. Nelayan perlu diedukasi untuk mampu memahami sistem teknologi satelit atau GPS. Meskipun mereka tidak mampu menggunakan teknologinya, nelayan dibukakan akses informasi, baik dari pihak DKP (Dinas Kelautan dan Perikanan), BMKG (Badan Meteorologi, Klimatologi, dan Geofisika), maupun syahbandar, sebagai pengelola kegiatan nelayan di tingkat lokal. Selain itu, dalam peningkatan kualitas ikan, dukungan pengusaha dan akademisi berkaitan dengan teknologi pengawetan dan pengemasan perlu diberikan agar harga ikan yang nelayan jual tetap stabil.

\section{Peran Pemerintah, Lembaga Non-pemerintah dan Akademisi untuk Kema- juan Teknologi bagi Masyarakat Pesisir}

Secara umum, kemiskinan masyarakat pesisir disebabkan oleh tidak terpenuhinya hak-hak dasar masyarakat, antara lain kebutuhan pangan, kesehatan, pendidikan, pekerjaan, dan infrastruktur. Di samping itu, kurangnya kesempatan berusaha, kurangnya akses terhadap informasi, teknologi dan permodalan, budaya dan gaya hidup yang cenderung boros, menyebabkan posisi tawar masyarakat miskin semakin lemah. Pada saat yang sama, kebijakan Pemerintah selama ini kurang berpihak pada masyarakat pesisir sebagai salah satu pemangku kepentingan di wilayah pesisir.

Banyak program yang telah dilakukan pemerintah untuk menanggulangi kemiskinan nelayan. Program yang bersifat umum berupa program pemerintah, antara lain Program Gerbang Emas, Program Anggur Merah, Program Pengembangan Usaha Agribisnis Perdesaan (PUAP), Program Nasional Pembangunan Masyarakat (PNPM), dan Kredit Usaha Rakyat (KUR). Namun, secara umum program-program tersebut tidak 
membuat nasib nelayan menjadi lebih baik daripada sebelumnya. Salah satu penyebab kurang berhasilnya program-program pemerintah tersebut dalam menanggulangi kemiskinan nelayan adalah formulasi kebijakan yang bersifat top down. Formula yang diberikan cenderung seragam, padahal masalah yang dihadapi nelayan sangat beragam dan seringkali sangat spesifik kedaerahan.

Pelatihan teknologi hasil perikanan yang dilakukan oleh lembaga non-pemerintah dan para akademisi pun dirasa masih sangat kurang karena luasnya wilayah pesisir Flores Timur, sehingga membuat banyak lokasi yang belum terjangkau.

\section{Tanggapan Masyarakat Pesisir terhadap Teknologi Modern}

Masyarakat pada umumnya sangat menerima kemajuan teknologi terutama di bidang perikanan, tetapi kendala yang sering terjadi adalah kurangnya informasi yang didapat oleh masyarakat. Selain itu, terjadi pula tebang pilih dalam proses pelatihan dan pembagian bantuan baik berupa modal kerja hingga kapal penangkap ikan.

Kehidupan sosial budaya masyarakat pesisir dan pulau-pulau kecil di Indonesia sangatlah beragam. Perkembanagan sosial budaya ini secara langsung dan tidak langsung dipengaruhi oleh faktor alam. Perkembangan lebih lanjut memberikan karakteristik dalam aktifitasnya mengelola sumber daya alam. Tidak jarang ditemukan bahwa masyarakat pesisir dan pulau-pulau kecil belum tentu memilih laut sebagai lahan mata pencaharian utama. Hal itu menunjukan pola dan karakter yang berbeda dari satu kawasan perairan ke kawasan perairan lain.

Adat istiadat suku yang bermukim di wilayah pesisir dan pulau-pulau kecil sangat beragam pula. Di beberapa tempat sering dijumpai adanya budaya pengaturan lahan laut atau sering disebut hak ulayat laut. Aturan-aturan semacam ini merupakan satu kearifan lokal yang perlu dihargai dan menghormati kesatuan-kesatuan masyarakat hukum adat beserta hak-hak tradisionalnya sepanjang hidup dan sesuai dengan perkembangan masyarakat dan prinsip Negara Kesatuan Republik Indonesia, yang diatur dengan Undang-Undang.

Kebudayaan masyarakat pesisir dapat diartikan sebagai keseluruhan pengetahuan atau sistem kognisi yang ada dan berkembang pada masyarakat pesisir, yang isinya adalah perangkat-perangkat model pengetahuan yang secara selektif dapat digunakan untuk memahami dan menginterpretasi lingkungan yang dihadapi untuk mendorong dan menciptakan kelakuan-kelakuan yang diperlukan.

\section{KESIMPULAN DAN SARAN}

Berdasarkan kajian ini, teknologi tradisional bermanfaat melestarikan budaya dan kearifan local, tetapi tidak menutup teknologi modern. Peran pemerintah melalui pendamping desa, lembaga non-pemerintah, dan akademisi melalui pelatihan belum menyentuh masyarakat karena luasnya area dan keterbatasan tenaga.

Berkaitan dengan diversifikasi pekerjaan dalam upaya meningkatkan kesejahteraan masyarakat nelayan, pemangku kepentingan diharapkan mampu mencarikan potensi baik kewilayahan maupun ketrampilan masyarakat nelayan. Hal ini perlu dilakukan, agar ada diversifikasi yang lebih menguntungkan. Apakah melalui upaya pengembangkan pariwisata setempat, pengolahan hasil tangkapan laut menjadi makanan khas, hingga upaya budidaya ikan. Selain itu, perlunya membangun jejaring komunikasi di antara 
pemangku kepentingan berdasarkan kapasitasnya. Misalnya, LSM (lembaga nonpemerintah) dengan memberikan pendampingan dan pelatihan, pemerintah memberikan dukungan perizinan dan fasilitas, serta pengusaha memberikan bantuan modal. Dengan konsep ini, diharapkan kondisi paceklik tidak akan terlalu besar mmeberikan dampak buruk bagi masyarakat nelayan, karena sudah terbentuk alternatif pekerjaan yang samasama menguntungkan.

Saran yang dapat diberikan berdasarkan hasil penelitian ini adalah: (1) Memperbanyak pelatihan bagi para nelayan, baik dari sisi kualitas maupun kuantitasnya untuk penanganan teknologi hasil perikanan secara modern; (2) Pelatihan harus diberikan kepada nelayan secara tepat; (3) Hasil pelatihan dapat dipasarkan secara berkelanjutan dengan pendampingan dari dinas terkait; (4) Mempermudah perizinan berlayar dan industri kecil bagi para nelayan; (5) Lembaga perbankan dan lembaga keuangan mikro dapat memberikan suntikan dana untuk pengembangan teknologi hasil perikanan bagi nelayan; (6) Para pengusaha dapat menjadi bapak angkat bagi nelayan-nelayan kecil dengan memberi pendampingan, menyediakan sarana-prasarana, dan membeli hasil tangkapan dengan harga yang layak; dan (7) Secara berkelanjutan, pemerintah melalui dinas terkait melakukan monitoring kepada nelayan yang telah didampingi agar hasil pelatihan dapat dievaluasi.

\section{DAFTAR REFERENSI}

BPS (2006). Berita Resmi BPS.

David, Fred R. (2006). Manajemen Strategis: Konsep. Edisi 10. Jakarta: Penerbit Salemba Empat.

Mudjahirin (2010). Sosiologi Pedesaan Masyarakat Jawa Pesisiran. Bandung: Universitas Diponegoro Press.

Nawastuti, D. (2017). Dinamika Permodalan pada Pedagang Ikan Bakulan di Pasar INPRES Larantuka Kabupaten Flores Timur. Jurnal Edukreasi, Vol. II No. 1, Hal. 43-50.

Nawastuti, D. \& Suryani, A. (2018). Manajemen Risiko Pada Penjualan Ikan Hasil Tangkapan Nelayan di Sepanjang Ruas Jalan Utama Larantuka-Boru. Seminar Nasional Perikanan XV, Universitas Gadjah Mada Yogyakarta, 28 Juli 2018.

Soekanto, S. (2006). Sosiologi Suatu Pengantar. Cetakan 38. Jakarta: PT. Grafindo Persada.

Suharto, E. (2005). Membangun Masyarakat Memberdayakan Rakyat; Kajian Strategis Kesejahteraan Sosial dan Pekerjaan Sosial. Bandung: CV Refika Aditama.

Sulviyana dkk. (2012). Kehidupan Sosial Ekonomi Masyarakat Pesisir. Kendari: Fakultas Kedokteran Universitas Haluoleo.

Satria, A. (2002). Dinamika Modernisasi Perikanan; Formasi Sosial dan Mobilitas Nelayan. Bandung: Humaniora Press.

https://id.wikipedia.org/wiki/Pesisir. Diakses tanggal 20 Maret 2017.

https://www.kemenperin.go.id. Diakses tanggal 19 April 2017.

https://id.wikipedia.org/wiki/Analisis_SWOT. Diakses tanggal 28 Agustus 2018.

https://www.rahmatullah.net. Diakses tanggal 10 Oktober 2018. 